nich m.in. pominięcie w indeksie rzeczowym niektórych ważnych terminów. Są to np. hasła:

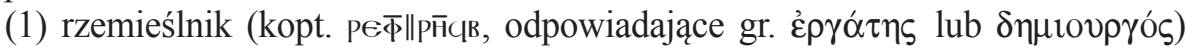
występuje w Tractatus Tripartitus (NHC I 5: 101,29; por. przekład s. 115);

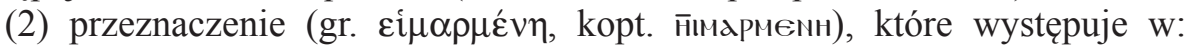
Apokryfie Jana (NHC II 2: 28, 21 i 28, 14-15 - gdzie pojawia się też w pisowni стмарменн) і $O$ początku świata (NHC II 5: 121,16 i 123,13), nawet jeśli autor w tłumaczeniach użył terminu „los” (por. s. 184, 336, 337) warto było uwzględnić je w odsyłaczu z uwagi na techniczny charakter terminu.

Są to jednak drobne przeoczenia, które szybko można uzupełnić w drugim wydaniu. Należy mieć nadzieję, iż Biblioteka z Nag Hammadi: kodeksy I i II stanowi pierwszy tom inicjujący wydanie polskich przekładów całej Biblioteki, czego życzę Autorowi i czytelnikom.

Anna Z. Zmorzanka - Lublin, KUL

\title{
Michele PICCIRILlO, La Palestina Cristiana I-VII secolo, Bologna 2008, EDB, ss. 226.
}

Autorem tej fascynującej książeczki jest zmarły niedawno (26 X 2008) w wieku 64 lat archeolog ze Studium franciszkańskiego w Jerozolimie. Książka sprawia wrażenie niedokończonej, jakby jej Autor, świadom zbliżającej się śmierci, spieszył się z przekazaniem swego przesłania. Faktycznie, ostatnia publikacja wielkiego uczonego stanowi syntezę jego badań, którym poświęcił całe życie. Sięga w niej bowiem do korzeni konfliktu, dzielącego dzisiaj mieszkańców Palestyny. Jako motto książki, a zarazem testament duchowy ojca Michele, można potraktować słowa jednego z mnichów palestyńskich, cytowane we wstępie: „Szacunek jest podstawą całej społeczności świętych. Zaprawdę mówię wam, bracia: Nie ma takiego poganina, żyda czy samarytanina, który nie byłby ukochany przez Boga i przez ludzi, jeśli tylko odznacza się prawdziwym szacunkiem i łagodnością. Każdy bowiem, kto czci i szanuje Boga, jest też przez Niego akceptowany" (Jerzy z Koziby).

W omawianej książce ojciec Piccirillo naszkicował historię sześciu wieków dawnej rzymskiej prowincji Palaestina (od jej powstania w 6 r. po Chr. do bitwy nad rzeką Jarmuk w 636 r., przegranej przez wojska bizantyjskie). Były to czasy decydujące dla dziejów chrześcijaństwa, a zarazem okres, w którym zrodziła się i umarła „herezja nazarejczyków”. W tym okresie upadła Jerozolima żydowska, aby odrodzić się po 150 latach jako miasto chrześcijańskie, „matka wszystkich kościołów”. Miejsca święte stanowią odtąd cel pielgrzymek, a „pustynia świętego miasta Jeruzalem" kwitnie życiem mniszym i świętością. Dopiero inwazja perska, a po niej arabska, położy kres tej szczególnej epoce. „Jeruzalem górne zapłacze nad Jeruzalem dolnym”.

Zarysowane tutaj tematy będą podjęte w kolejnych rozdziałach pasjonującej książki o. Michele Piccirillo. Rozdział I (s. 23-51) dotyczy więc narodzin wspól- 
noty chrześcijańskiej w Palestynie i jej trudnych początków, aż do edyktu mediolańskiego. Rozdział II (s. 55-68) rozwija temat „nowego Syjonu” i rozwoju wspólnoty chrześcijańskiej w Jerozolimie w wiekach IV-VI. Obszerny rozdział III (s. 71-109) obejmuje dość luźno powiązane ze sobą wydarzenia z historii Ziemi Świętej w czasach od Konstantyna Wielkiego do Justyniana.

Dalsza część książki jest już bardziej zwarta tematycznie. Rozdział IV (s. 113136) poświęcony jest życiu pustelniczemu na Pustyni Judzkiej. Tutaj Autor zapoznaje czytelników z cennymi badaniami archeologicznymi, jakich tam dokonano w ostatnich dziesięcioleciach. Odbiciem zainteresowań o. Michele jest zwłaszcza końcowa partia tego rozdziału, poświęcona ojcom pustyni, którzy wnieśli szczególny wkład w budowanie pokoju pomiędzy zwaśnionymi stronami.

Rozdział V (s. 139-163) dotyczy w całości miejsc świętych, ich liturgii i teologii. Zaczynając od wizyty cesarzowej Heleny w Ziemi Świętej i odnalezienia relikwii Krzyża Chrystusowego, omawia Autor sanktuaria odwiedzane przez starożytnych pielgrzymów, zarówno w Jerozolimie i Judei, jak również w trudniej dostępnej Galilei; zrozumiałe, że najwięcej miejsca poświęcono tutaj świadectwu pątniczki Egerii z końca IV wieku. W ostatnim VI rozdziale (s. 167-201) omówił o. Piccirillo końcową epokę dziejów „Palestyny chrześcijańskiej”, a więc okres inwazji perskiej (614) i wkrótce potem - arabskiej. Podobnie, jak w całej książce, opowieść historyczna przeplata się tutaj z cennymi uwagami archeologa, który dzieli się z czytelnikiem wynikami swych badań. Dzięki temu zabiegowi lektura książki nie jest nużąca, lecz zachęca adresata do zapoznania się z bogatą dokumentacją źródłową.

Cennym dodatkiem są tablice chronologiczne (s. 203-210), które ułatwiają śledzenie skomplikowanych dziejów Ziemi Świętej podczas tych kilku burzliwych stuleci. Na tle listy cesarzy rzymskich i bizantyjskich zostały tu ukazane najważniejsze wydarzenia opisane w książce. Całość zamyka obszerny wykaz literatury przedmiotu, zwłaszcza starożytnych źródeł, tylko częściowo dostępnych w polskim przekładzie. Książka, będąca w jakiejś mierze podsumowaniem pracy o. Michele Piccirillo, zasługuje na rychłe jej udostępnienie polskim czytelnikom. Wówczas bibliografię obcojęzyczną warto uzupełnić o nieliczne opracowania polskie, korzystając z cennych zestawów publikowanych systematycznie przez „Vox Patrum” . $\mathrm{Z}$ uwagi na rzetelność omawianej pracy, można ją śmiało polecać jako lekturę uzupełniającą studentom teologii i historii starożytnej, a zwłaszcza biblistyki.

Bolońskie wydawnictwo Dehoniana zadbało również o zewnętrzną formę książki, nadając jej wygodny format przewodników turystycznych. Jest to sygnał dla czytelnika, że może z jej lektury wiele skorzystać podczas pielgrzymki do Ziemi Świętej. Największą wartością tej książki jest jednak osobiste świadectwo wybitnego archeologa i franciszkanina, autentycznie zatroskanego o budowanie pokoju wśród zwaśnionych mieszkańców ojczyzny Chrystusa.

Ks. Antoni Tronina - Lublin, KUL 